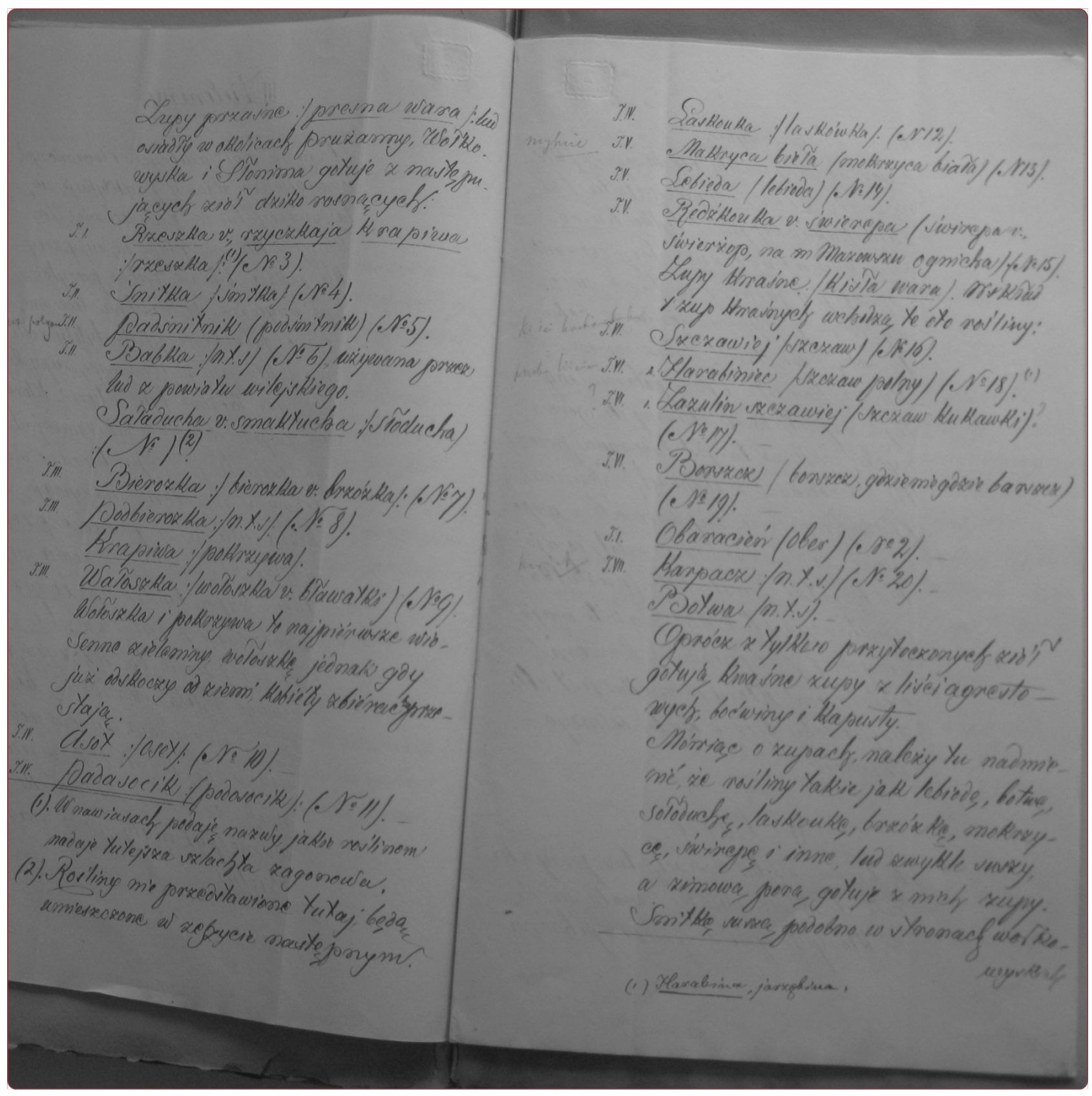

\title{
Wild edible plants of Belarus: from Rostafiński's questionnaire of 1883 to the present
}

Łuczaj et al. 


\title{
Wild edible plants of Belarus: from Rostafiński's questionnaire of 1883 to the present
}

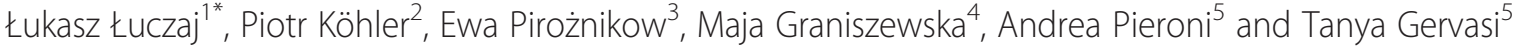

\begin{abstract}
Background: Belarus is an Eastern European country, which has been little studied ethnobotanically. The aim of the study was to compare largely unpublished 19th century sources with more contemporary data on the use of wild food plants.

Methods: The information on 19th century uses is based on twelve, mainly unpublished, responses to Józef Rostafiński's questionnaire from 1883, and the newly discovered materials of the ethnographer Michał Federowski, who structured his data according to Rostafiński's questionnaire and documented it with voucher specimens. Rostafiński's questionnaire was concerned mainly with Polish territories, but for historical reasons this also encompassed a large part of Belarus, and we analyzed only the twelve responses (out of the few hundred Rostafiński obtained), which concerned the present Belarus. These data were compared with a few 20th century ethnographic sources, and our own 40 interviews and questionnaires from Belarus.
\end{abstract}

Results and discussion: 58 taxa of wild food plants used in the 19th century were identified. Some of them are still used in modern Belarus, others are probably completely forgotten. In the 19th century several species of wild greens were widely used for making soups. Apart from Rumex, other wild greens are now either forgotten or rarely used. The list of species used in the 20th and 21st century encompasses 67 taxa. Nearly half of them were mentioned by Rostafiński's respondents. The list of fruit species has not changed much, although in the 19th century fruits were mainly eaten raw, or with dairy or floury dishes, and now apart from being eaten raw, they are incorporated in sweet dishes like jams or cakes. Modern comparative data also contain several alien species, some of which have escaped from cultivation and are gathered from a semi-wild state, as well as children's snacks, which were probably collected in the 19th century but were not recorded back then.

Conclusion: The responses to Rostafiński from 1883 present extremely valuable historical material as the use of wild food plants in Belarus has since undergone drastic changes, similar to those, which have taken place in other Eastern European countries.

Keywords: Historical ethnobotany, Wild green vegetables, Wild food plants, Non-timber forest products, Belarus

\section{Background}

There has been a renewed interest in wild food plants in recent years due to world-wide concerns about the quality of food made from mass-produced crop plants, which are poor in micronutrients and grown in petroleum based agricultural systems [1-5]. At the same time, old traditions of plant gathering in most countries are being lost and need recording and preserving. This is also relevant for

\footnotetext{
* Correspondence: lukasz.luczaj@interia.pl

'Institute of Applied Biotechnology and Basic Sciences, Department of Botany and Biotechnology of Economic Plants, University of Rzeszów, Werynia 502, 36-100 Kolbuszowa, Poland

Full list of author information is available at the end of the article
}

Eastern Europe. Fortunately in this part of the world many nineteenth and early twentieth century studies have managed to capture disappearing plant uses. This is one of the few places in the world where diachronic studies ranging over the period of a century are possible. Over the last few years, reviews of archival ethnographic studies concerning wild food plant use have been published in some eastern and northern European countries: Poland [6-8], Estonia [9], Hungary [10], Sweden [11] and Slovakia [12]. These reviews brought the majority of wild food plant literature and data together, enabling inter-country and inter-region comparisons. It also makes this data available for an 
international readership, as they were originally, predominantly published in their national languages. However, some eastern European countries still remain terra incognita for modern ethnobotany. One of them is Belarus. We have not found any modern ethnobotanical studies concerning this country, apart from a short FAO report on crop genetic resources [13]. At the same time it is a country with a very rich folklore. It was Kazimierz Moszyński (1887-1959), the author of Kultura ludowa Stowian (the Folk culture of Slavs), who pointed out that the present area of Belarus is one of the parts of Europe where many vestiges of traditional culture had been preserved $[14,15]$. He made a few expeditions to the Belarusian region of Polesia himself [16] and published an ethnographic monograph of its eastern parts [17]. For many decades, Belarus was treated by Polish ethnographers as one of the most interesting, "archaic" and "backward" places of the former Polish-Lithuanian Commonwealth, ideal for ethnographic research. Even today, due to its political isolation and the fact that a part of its population still lives in traditional-style villages scattered over this heavily wooded country, Belarus is a very important place for European ethnobiology.

Moszyński was not the only Polish ethnographer fascinated with Belarus. Here we should list two other ethnographers: Michał Federowski (1853-1923) and Józef Obrębski (1905-1967). Late 19th century folklore concerning the use of medicinal plants was recorded by the afore-mentioned Federowski in the first volume of his "Lud Białoruski" ("Belarusian Folk") [18] as well as by one of the leading Polish writers of that time, Eliza Orzeszkowa (1841-1910) [19-28]. What is amazing is that both of them left rich, detailed herbaria documenting the names of plants and their uses. The second and third parts of Federowski's herbarium are kept in the library of Warsaw University [29] and Orzeszkowa's main herbarium is stored in Poznań [24-28]. The first part of Federowski's herbarium was regarded as lost until last year, when it was discovered by one of the coauthors of the article (M.G.). Additional sources of information are the materials gathered by local researcher, Zośka Wieras [30]. Thus we can conclude that the 19th century use of medicinal plants in some parts of Belarus is relatively well documented. Unfortunately, very little information has been published on the use of wild food plants from the same territory $[17,31]$. At the same time a large and well documented set of observations on the use of wild food plants in 19th century Belarus, made up of responses to Rostafiński's questionnaire (mainly from 1883), is stored in two Polish botanical institutions, with most data still unpublished [31-36]. As the files of Rostafiński's questionnaire are some of the most important ethnobotanical documents in Europe, enabling us to draw a detailed picture of the use of wild plants in Belarus at the end of the 19th century, we decided to devote a separate article to them. Our aim was to compare their content with the scattered modern data on wild food plants in Belarus.

\section{Methods}

\section{Belarus as a study area}

The state of Belarus is located in Eastern Europe. It has an area of 207 thousand $\mathrm{km}^{2}$ and a population of 9.5 mln (according to the 2012 census). The population density is relatively low (46 people $/ \mathrm{km}^{2}$ ). Belarus is a landlocked lowland country with predominantly postglacial landform. Areas of sandy soils are mixed with clays, marshes and peat-bogs. The southern part of the country (Polesia region) is very marshy. A large proportion of the population (ca. two million) lives in the capital city, Minsk. Belarus is located in an area of humid continental climate. The forest vegetation is composed of both coniferous and deciduous species. Pinus sylvestris, Picea abies, Alnus glutinosa, Betula pendula and Quercus robur are the dominant trees in the heavily wooded landscape (forest cover ca. 40\%) [37]. The vascular flora of Belarus contains around 1860 species [38].

Belarus was one of the core parts of the Kievan Rus'. In medieval times it was a part of the Principality of Polotsk, the Grand Duchy of Lithuania, then the PolishLithuanian Commonwealth. Later, at the end of the 18th century, through the partitions of the Commonwealth, it became part of the Russian Empire. After World War I, the territory of Belarus was divided between Poland and the Soviet Belarusian Republic (the latter within Soviet Union). In 1939, the Polish part of Belarus was annexed by the Soviet Union and merged with the Soviet Belarusian Republic. After World War II, most of the large Polish minority left Belarus (now it constitutes only $3 \%$ of the population). After the collapse of the Soviet Union, it became an independent state in 1991. At the moment the Belarusian nationality dominates in the population, however, two closely related languages are official: Russian and Belarusian, with the former dominating in cities. The main minorities are Russians, Poles and Ukrainians [38-40].

Belarusian cuisine is dominated by potato dishes and bread. Dairy products and pastry dishes (i.e. dumplings) are also eaten on an everyday basis. Soups have been also a major part of dinner. Many dishes are made using fermented ingredients (sourdough bread, sourdough soups, lacto-fermented salads made from cabbage, cucumbers and tomatoes, fermented birch sap etc.) [41,42].

\section{Characteristics of Rostafiński's questionnaire}

Professor Józef Rostafiński (1850-1928), a Polish botanist from Kraków (Jagiellonian University), composed a 70-question questionnaire concerning all aspects of ethnobotany (traditional cultivated and wild foods, medicine, rituals, dyes etc.). The survey was called "Odezwa 
do nie botaników o zbieranie ludowych nazw roślin", which translates as "An appeal to non-botanists to collect folk plant names". In its largest version it included 70 questions concerning the use of plants, their cultivation, gathering and naming. It was published in 1883 in around 60 Polish language newspapers in Prussia, Austro-Hungary and Russia (at that time Poland was divided into these three empires). Rostafiński received a few hundred responses, which have been partly preserved up to the present and constitute probably the largest ethnobotanical survey of 19th century Europe. The known letters come from the years 1883-1909 (mainly 1883-84). Out of around two hundred authors who wrote to him, most sent him information concerning the contemporary territory of Poland. However, several of them reported the use of plants in the present territory of Belarus and western Ukraine, for historical reasons, as a large proportion of intelligentsia and landowners (typical of Rostafiński's respondents) in these countries were either Polish or Polonized. In their letters they mostly referred to plants grown or cultivated by peasants, though sometimes they also supplied details on the plants used in manors [31-36].

Responses to Rostafiński were only partly used by their owner and remained, forgotten, in the Jagiellonian University for decades. They were "discovered" at the end of the 20th century on the premises of the Institute of Botany and are stored in the Museum of the Botanic Garden of the Jagiellonian University [31-36]. Twelve of them contain information on the present Belarus and were analyzed in this paper (Table 1). Most of the information contained in them and the original text have not been published, apart from scattered notes on the use of some species (Heracleum and Aegopodium - $[8,36]$, tree saps - $[8,36,43])$. The correspondence with one respondent, Maria Twardowska, was characterized in a separate paper [31].

Apart from them, in 2012, another response to Rostafiński's questionnaire was found by one of the coauthors of this article (M.G.) in the herbarium of the Warsaw University. This never-sent response belongs to Michał Federowski vel Fedorowski (an ethnographer working in Belarus mentioned in the Background section of this article). It contains a separate folder with responses to Rostafiński's questionnaire titled "Rośliny użyteczne u ludu litewskiego okolic Słonima, Wołkowyska i Prużanny. Zeszyt I. Zebrał i opisał Michał Fedorowski" (i.e. "Useful plants of Lithuanian peasants in the area of Słonim, Wołkowysk and Prużanna. Volume I. Collected and described by Michał Fedorowski"), including an appendix describing the use of forest trees in this area and a herbarium documenting the plants mentioned in the text, as well as another file, which is a previously unknown part of Federowski's herbarium of medicinal plants documenting his chapter in "Lud Białoruski" [18] ("Zioła lecznicze używane przez lud litewski w okolicach Wołkowyska i Słonima $\mathrm{z}$ dodatkiem roślin $\mathrm{w}$ gusłach i czarach zastosowanie mających. Zeszyt II. Zebrał i opisał Michał Fedorowski", i.e. "Medicinal herbs used by Lithuanian peasants in the area of Wołkowysk and Słonim with the addition of plants used in superstitions and magic. Volume II. Collected and described by Michał Fedorowski"; the other two parts have been deposited in the library of Warsaw University). "Lud Białoruski", as its author stated, contains material gathered between 1879 and 1891, but the date of the manuscript is "November 1883" (straight after the publication of Rostafińki's questionnaire). It is not sure if Federowski ever thought of sending the materials to Rostafiński. It is also possible that he found his questionnaire a useful framework for his own work. This part of the herbarium, concerning non-medicinal uses must have been assembled from the plants he had dried earlier.

Rostafiński's questionnaire included several questions concerning the use of wild food plants:

"6) Is ber [Setaria italica] grown? do people gather wild ber and other wild grasses, particularly:

7) manna, mielec [both refer to Glyceria], stokłosa [Bromus], in what quantities, do people use it themselves or bring it to town market?

21) Do people know (at least from tradition) the names kucmerka and stodyczka? [the question referred to old names of Sium sisarum, but yielded answers for the use of Stachys palustris and Polypodium vulgare, for details see [50].

23) Do local people gather herbs in spring to be used in soups, particularly in famine years, and these herbs are?".

This is followed by questions 24-33, in which he asks if people know the names of particular plants. These seem like continuations of question 23, as most of the listed plants are green vegetables: Urtica (as pokrzywa, żegawka) and Glechoma (as kurdybanek, bluszczyk) no. 25, Rumex and Oxalis (as szczaw, zajęcza kapusta) no. 26, Heracleum (as barszcz "plant" - to differentiate it from the soup also called barszcz) - no. 27, Aegopodium podagraria (as gir, girz in no. 28, and śnitka in no. 32) and Artemisia abrotanum [as Boże drzewko] "or other plants fried with butter". In the responses to these names people usually reported not only local names but also the way these species were eaten.

And further:

“34) Salads and herbs eaten raw, which [plants]? 
Table 1 Characteristics of Rostafiński's respondents and the location of places they wrote about

\begin{tabular}{|c|c|c|c|c|}
\hline $\begin{array}{l}\text { Place for which } \\
\text { information was given } \\
\text { (the present Belarusian }\end{array}$ & Region or county & Code & $\begin{array}{l}\text { Surname, First } \\
\text { name }\end{array}$ & Biographical information \\
\hline
\end{tabular}

name given in brackets)

\begin{tabular}{|c|c|c|c|c|}
\hline \multicolumn{5}{|c|}{ Materials stored in the Museum of the Botanic Garden of the Jagiellonian University, ul. Kopernika 27, Kraków } \\
\hline Nieśwież, Słuck and Mińsk & \multirow[t]{2}{*}{ Mińsk (Minsk) } & \multirow[t]{2}{*}{ CZA } & \multirow[t]{2}{*}{ Czarnocka, Helena } & \multirow{2}{*}{$\begin{array}{l}\text { landowner, sent her letters from Secieszyn (Kleck train } \\
\text { stop, Minsk gubernya) }\end{array}$} \\
\hline (Nyasvizh, Sluck, Minsk) & & & & \\
\hline Jeziora (Azyory) & Grodno (Hrodna) & KOR & $\begin{array}{l}\text { Korycińska, } \\
\text { Aleksandra }\end{array}$ & $\begin{array}{l}\text { no data; wrote her letter from Warsaw, passing on } \\
\text { information from her friends }\end{array}$ \\
\hline $\begin{array}{l}\text { Bobrzyńsk near Bobrujsk } \\
\text { (now Babruysk) and } \\
\text { surrounding counties }\end{array}$ & Mohylew (Mohilew) & LAS & $\begin{array}{l}\text { Laskarys, Antonina } \\
\text { z Zabiełtów }\end{array}$ & (1835 in Vilnius - ?), landowner [44] \\
\hline Naliboki & Mińsk (Minsk) & LES & Łęski, Michał & landowner from Chotów \\
\hline Puków & Ihumeń (Chervyen') & NAR & $\begin{array}{l}\text { Narkiewicz-Jodko, } \\
\text { Tomasz }\end{array}$ & (ok. 1840 -?), landowner (Puków estate in Minsk gubernya) \\
\hline Pińsk and around (Pinsk) & Pińsk (Pinsk) & $\mathrm{ONU}$ & Onufrowicz, Adam & $\begin{array}{l}\text { (1856-1914), studied at the Institute of Mining in St. } \\
\text { Petersburg and the Technical Academy in Kraków, taught } \\
\text { in polytechnics in Austro-Hungary and Russia. He was the } \\
\text { main director of a factory in Kysztyma [45] }\end{array}$ \\
\hline Kuchcice and Chołuj & Ihumeń (Chervyen') & OSS & Ossowski, Antoni & no data \\
\hline Rawonicze & Ihumeń (Chervyen') & SLO & Słotwińska, J & no data \\
\hline whole counties & $\begin{array}{l}\text { Pińsk, Mozyrz, Rzeczyca } \\
\text { (Pinsk, Mazyr, Rechytsa) }\end{array}$ & SLO & Słotwińska, J & \\
\hline Weleśnica & Pińsk (Pinsk) & TWA & Twardowska, Maria & $\begin{array}{l}\text { (1858-1907), botanist (florist), authored several publications } \\
\text { on the flora of the Vilnius region and Polesia [46-48] }\end{array}$ \\
\hline n.d. & Pińsk (Pinsk) & NIE & Nielubowicz, W. & landowner \\
\hline $\begin{array}{l}\text { Nowogródek } \\
\text { (Navahrudak) }\end{array}$ & Grodno (Hrodna) & DYB & $\begin{array}{l}\text { Dybowski, } \\
\text { Władysław }\end{array}$ & $\begin{array}{l}\text { (1838-1910), zoologist and botanist, master of mineralogy } \\
\text { (1873), privatdozent of general paleontology in the university } \\
\text { of Dorpat (now Tartu) (1876); when he responded to } \\
\text { Rostafiński he was leasing an estate in Niańków near } \\
\text { Nowogródek [49] }\end{array}$ \\
\hline Lipów & Rzeczyca (Rechytsa) & WOJ & $\begin{array}{l}\text { Woyniłłowiczówna, } \\
\text { Jadwiga }\end{array}$ & no data \\
\hline
\end{tabular}

Manuscript and herbarium stored in the Herbarium of the Faculty of Biology of the University of Warsaw, Al. Ujazdowskie 4, Warsaw

whole counties Wołkowysk, Słonim, Prużany FED Federowski, Michał (1853-1923), amateur ethnographer, the leading researcher Vawkavysk, Slonim, of Belarusian verbal and musical folklore; worked on manorial

Pruzhany) estates, gathered many volumes of data on Belarusian folklore, e.g. [18]; lived in the presen territory of Belarus for most of the time between 1877and World War l; he wrote his answer to Rostafiński's quest. from Studerowszczyzna

All the letters were written in 1883, apart from Korycińska (1884).

43) What do the names wiśnie [sour cherry], trześnie [wild sweet cherry], czeremchy [chokecherry] mean in a given place?

44) Is the name dracz known for barberry? What berries do people know and under what names: a) raspberry-type composed fruit: pink like raspberry or dark blue, shiny like plums (blackberry), b) currants, red and black with stinking leaves, c) gooseberry, d) strawberry, e) small undershrubs with shiny leaves and round berries, red (brusznice, kamionki) or black (borówki and tohynie vel pijanice), f) with more oblong berries[,] cranberries, Cornelian cherry? Or other names?
50) Are nigella, coriander, dill, fennel, anise and caraway cultivated in manor gardens? [although these are mainly cultivated species, the question yielded answers on the use of wild caraway]

58) Do people buy culinary oil or make it themselves? From what? Flax? Cannabis? Poppy (grey or white), sunflower, rape? Or from traditionally used ingredients? [some of the answers concerned wild taxa]"

We also extracted information on wild food plants from the remainder of the letters sent in response to Rostafiński, sometimes in the form of digressions or loose observations. 
Thirteen responses to Rostafiński's questionnaire were analyzed (including the Federowski's materials). The information contained in them comes from many places in Belarus: from the south and south-east (Polesia), west (Hrodna, Vawkavysk, Pruzhany, Slonim), central part (e.g. Minsk and Ihumen'/Chyerven'), and north (Vileyka) (Figure 1). In many cases the respondents supplied Latin names of the plants they mentioned. Federowski additionally provided voucher specimens for most of the plants he reported (Figure 2). For nearly every plant he also provided a separate note on its use and, separately, the Belarusian peasant name and the name used by the Polish szlachta zaściankowa (i.e. poorer mainly Polish landowners of noble origin), who often farmed the land themselves but held Polish aristocratic titles and coats of arms. The north-western part of Belarus which Federowski studied was a nearly equal mixture of these two social and ethnic groups.

\section{0th and 21st century data}

In order to relate the data from Rostafiński's questionnaire to the present-day use of plants in Belarus, we tried to gather the scattered data on the use of wild food plants in the 20th and 21st centuries:

- One of the authors (T.G), in 2010 and 2011, interviewed middle-aged and elderly women (aged 45-85) about the use of all food plants (from three locations: the Minsk agglomeration $(n=19)$, the village of Katka (in the Mohilev region, $n=10$ ) and the village Galyenchitsy (near Ivatsyevichi, in the Brest region, $n=1$ ), as a part of a bachelor's thesis supervised by another co-author (A.P.), who also took part in some of the interviews.

- The list of plants was extended by interviews and questionnaires supplied by E.P. $(n=10)$, carried out in 2010-12. This includes five lists of traditional wild food compiled by Belarusian botanists (based on their autobiographical observations from their home places): Dr Oleg Sosinov, associate professor in the Faculty of Botany, University of Hrodna, information from: Kapyl' county (Minsk region) and Hrodna county, Dr Alla Aleksandrovna Pogodzkaya, Faculty of Pharmacognosy, Vitebsk State Medical University, (info from Homyel' region), three botanists from the Belarusian Bielovyezhskaya Pushcha National Park; two with E.P.'s elderly family members came from the villages around Hlybokaye (Vitebsk region) and three interviews carried out in the Bryest and Hrodna regions by E.P.'s students of Belarusian origin (carried out with their own elderly family members).

- Information from two 20th century publications containing data on wild food plant use in southern Belarus (Polesia) [17,51-53].

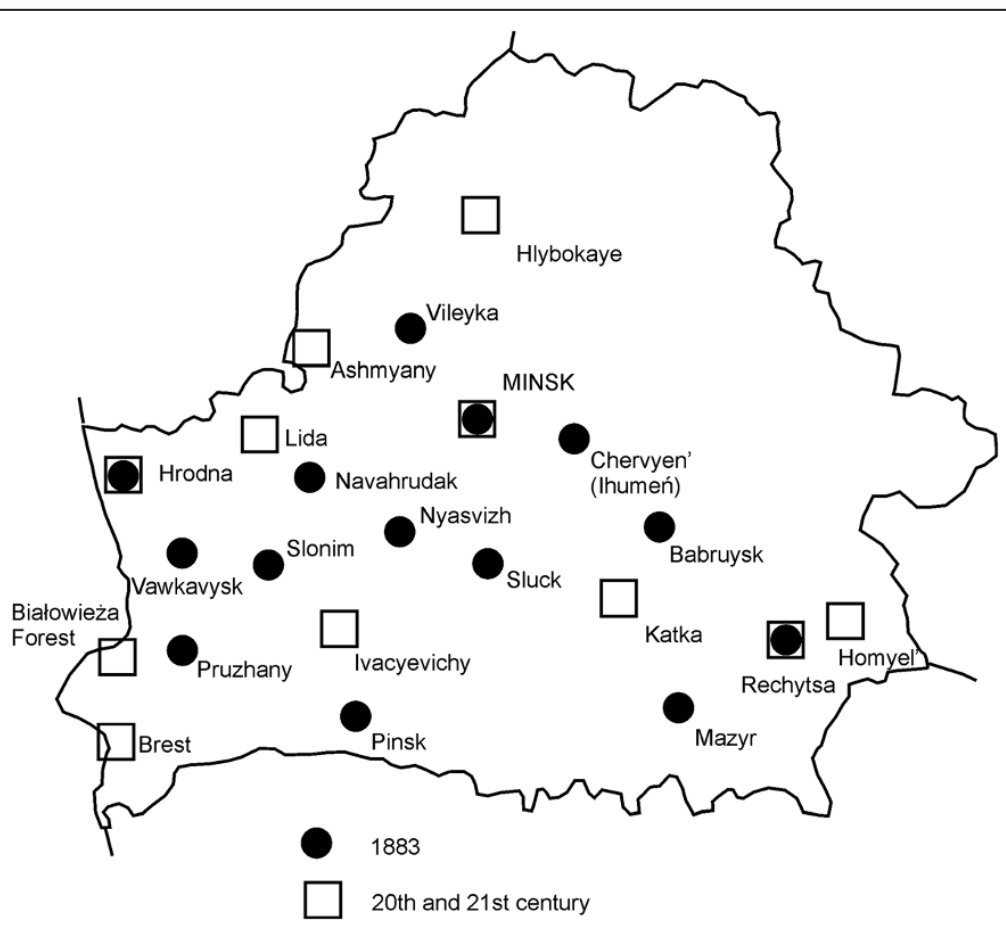

Figure 1 The location of information on plant uses, in most cases county towns, are marked but the information concerns the whole county. 


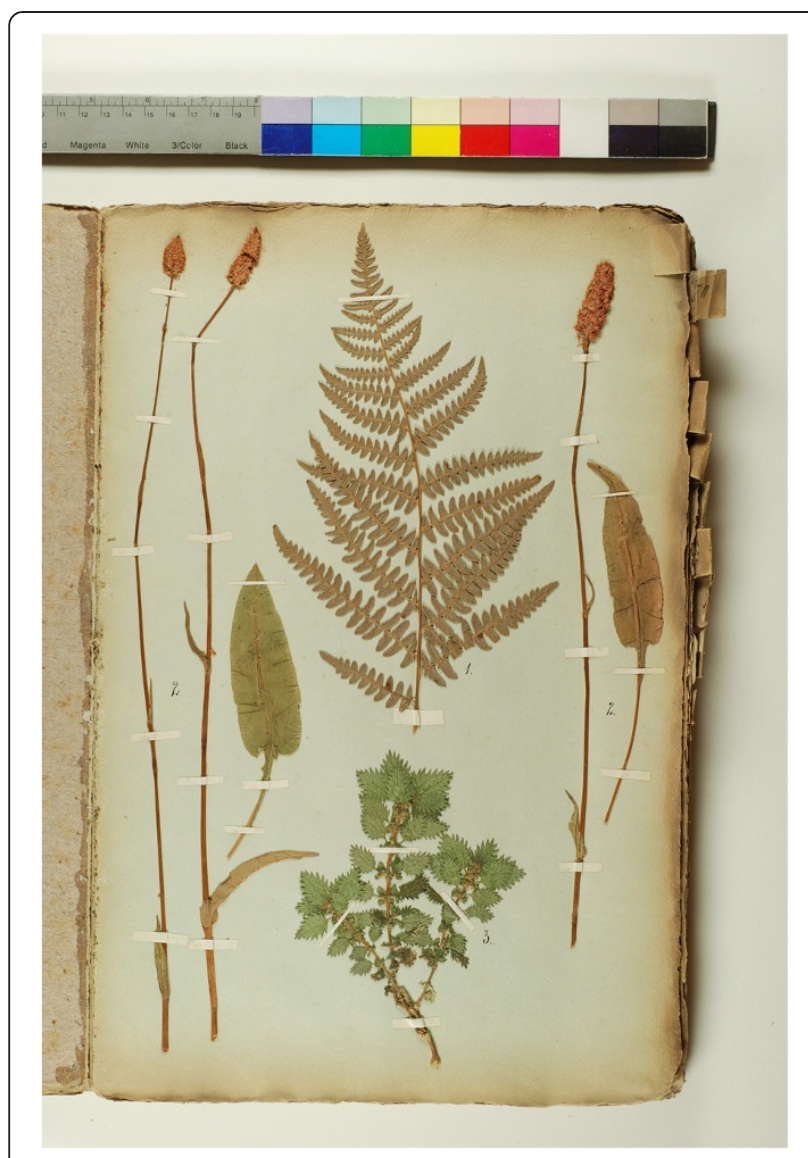

Figure 2 The first page of Federowski's herbarium.

- Retrospectives of settlers who moved from Belarus to Poland after World War II (in the questionnaires of the Polish Ethnographic Atlas from 1948 and 196469, for the characteristics of this source see [8]).

- Archives of the Polish ethnographer Adam Fischer stored in the library of the Polish Folklorist Society in Wrocław were searched for material concerning Belarus; five notes on the use of plants were found, three from Narbutowszczyzna near Oszmiana (now Ashmyany), based on herbarium specimens sent by Zofia Koczorowska to Fischer, probably in the 192030s, the note on Acorus comes from the Lida area and the note on Prunella from Antyczkowo, near Oszmiana).

- A Belarusian Internet culinary forums was searched in order to find out which of the listed plants are still a part of everyday culture (not included in Table 2).

- An additional source of comparison (not included in Table 2) was data on plant use in Belarusian villages in NE Poland, adjacent to the border with Belarus, from over two hundred interviews carried out by one of the co-authors (E.P.) [54,55].
The contemporary data are presented using transliteration of the Cyrillic alphabet for Belarusian/Russian names and using the official Polish orthography for Polish names. Belarusian plant names and contemporary geographical names were Romanized using the BGN/ PCGN standard used by the United States Board on Geographic Names and by the Permanent Committee on Geographical Names for British Official Use [56].

\section{Results}

Fifty-eight identified botanical species were mentioned altogether by Rostafiński's respondents from Belarus. Five taxa remained unidentified (Table 3). The largest category is composed of the green parts of plants (27 species), which were usually consumed in the form of soups (23 species). Two kinds of soups were distinguished: sour (kisla vara) and non-sour (presna vara). The first was made by leaving the ingredients to ferment for a few days or by adding acidic ingredients. Sorrel (Rumex spp.), ground elder (Aegopodium podagraria) and hogweed (Heracleum sphondylium s.l.) were used in sour soups. Nettle (Urtica spp.) and fat hen (Chenopodium album) were, according to Federowski, made into non-sour soups, though other data suggest that sometimes they occurred in sour soups as well and that this division is not very sharp. Sorrel was sour by itself, whereas hogweed was probably lacto-fermented. Soured birch and maple sap were also added to wild vegetable soups (e.g. with ground elder) to make them sour. According to Federowski one of the wild vegetables were commonly dried for winter use. Apart from the wild plants his herbarium also contains two cultivated species (thus not included in Table 2) eaten raw as salads: Borago officinalis L. (voucher specimen 21; hurecznik, ahurecznik/ogórecznik eaten with cream and salt) and Tropaeolum majus L. (22; nastulek, nastulka, flowers eaten with cultivated lettuce). He also mentions the raw use of some wild lettuce called zieziulina satata, but does not provide a specimen.

The second largest category, 18 species, was made up of fleshy fruits. Fruits in 19th century Belarus were mainly eaten raw, as a few of Rostafiński's respondents pointed out. Sometimes they were incorporated into dishes with milk or dough (soup, dumplings, kisiel/kisyel). Only manors prepared more sophisticated wild fruit desserts containing sugar.

A few spices are also mentioned, such as the fruits of Carum carvi, roots of Armoracia rusticana or aromatic leaves put under baking bread (Quercus robur, Acorus calamus).

No underground wild plant organs were gathered apart from the already mentioned horseradish and bracken (Pteridium aquilinum) rhizomes used only in the Vileyka region: during bad harvest years dried bracken was 
Table 2 Contemporary use of wild food plants (20-21th century)

Modern local name (transliterated from Part

Cyrillic apart from Polish names following

Part

20th -21 th century use

Source

Polish orthography (marked PL)

\begin{tabular}{|c|c|c|c|c|}
\hline Acer platanoides $\mathrm{L}$. & klyon, yavor & leaves & leaves under baking bread & EP \\
\hline Acorus calamus $\mathrm{L}$. & ayer (also PL), air, babki & leaves, shoot center & $\begin{array}{l}\text { leaves under baking bread, formerly; shoots } \\
\text { formerly as a spring snack }\end{array}$ & {$[51], E P, F S$} \\
\hline Aegopodium podagraria L. & snitka & leaves & soup & EP \\
\hline Allium sp. ? & PL: dziki czosnek & leaves & spice & EP \\
\hline Allium ursinum $\mathrm{L}$. & cheremsha & leaves & raw & EP \\
\hline Aquilegia vulgaris $\mathrm{L}$. & vodosbor & nectar & raw children's snack & EP \\
\hline $\begin{array}{l}\text { Armoracia rusticana G.Gaertn., } \\
\text { B.Mey. \& Schreb }\end{array}$ & khren & roots and leaves & $\begin{array}{l}\text { roots - grated into a spicy paste called kren } \\
\text { or added to dishes as spice, leaves as spice } \\
\text { for fermented sauerkraut, } \\
\text { cucumbers and tomatoes, and soups }\end{array}$ & $\mathrm{TG}, \mathrm{EP}$ \\
\hline Artemisia absinthium $\mathrm{L}$. & polyn' & leaves & herbal teas & EP \\
\hline Berberis vulgaris $L$. & n.d. & fruit & raw, snack, juice or salted & EP \\
\hline \multirow[t]{2}{*}{ Betula spp. } & byeryoza & sap & $\begin{array}{l}\text { fresh and fermented (such drink is called } \\
\text { byarozavik) }\end{array}$ & $\mathrm{TG}, \mathrm{EP}, \mathrm{PAE}$ \\
\hline & & wood shavings & $\begin{array}{l}\text { "eaten" (probably added to bread as famine } \\
\text { food) }\end{array}$ & FS \\
\hline Carum carvi $\mathrm{L}$. & tmin, kmin & fruits & spice for bread and sauerkraut & $T G, E P$ \\
\hline Chamomilla recutita (L.) Rauschert & n.d. & inflorescences & herbal tea & EP \\
\hline Chenopodium album L. & labadá (mistakenly as Atriplex), PL: lebioda & leaves & formerly in soups & [51], FS \\
\hline Corylus avellana L. & oryekh, aryekh, aryéshnik, lyeshina, & fruits & mainly raw & {$[17,51], \mathrm{EP}$} \\
\hline Crataegus sp. & boyáryshnik & fruits ("jablochki") & fresh and in jams, wine & $\mathrm{TG}, \mathrm{EP}$ \\
\hline Dactylis glomerata L. & yezha & stalk & inner part as a snack & EP \\
\hline Fragaria spp., mainly F. vesca L. & sunítsa, zyemlyanika & fruits & $\begin{array}{l}\text { raw, jams, wine etc., formerly also eaten with } \\
\text { milk and cream }\end{array}$ & {$[17,51]$, EP } \\
\hline Glyceria fluitans (L.) R.Br. & manna, máyna & grains & used until late 1940s to make kasha & {$[17,52,53]$, PAE } \\
\hline Hippophaë rhamnoides L. * & oblyepikha & fruits & fresh, juice, jams & TG \\
\hline Humulus lupulus L. & khmyel' & fruits & $\begin{array}{l}\text { formerly dried, spice for beer and mead and } \\
\text { added to bread dough }\end{array}$ & {$[17,51], \mathrm{EP}$} \\
\hline Juniperus communis L. & n.d. & pseudo-fruits & $\begin{array}{l}\text { raw children's snack, spice for food and alcoholic } \\
\text { beverages }\end{array}$ & EP \\
\hline Lamium album $\mathrm{L}$. & n.d. & nectar & raw children's snack & EP \\
\hline Linaria vulgaris $\mathrm{L}$. & I'vinyy zyev & nectar & raw children's snack & EP \\
\hline Lotus corniculatus L. & miadunka & nectar from flowers & raw children's snack & EP \\
\hline
\end{tabular}


Table 2 Contemporary use of wild food plants (20-21th century) (Continued)

\begin{tabular}{|c|c|c|c|c|}
\hline $\begin{array}{l}\text { Malus sylvestris Miller or Malus } \\
\text { domestica Borkh. }\end{array}$ & yáblyki & fruits & $\begin{array}{l}\text { eaten raw, dried, lactofermented in sauerkraut } \\
\text { or boiled }\end{array}$ & {$[17,51]$} \\
\hline Malva pusilla Sm. & yagodki & immature fruits & raw children's snack & EP \\
\hline Nymphaea alba L. & mákowka (for fruits), húski (for the plant) & seeds & raw as a snack & [17] \\
\hline Oxalis acetosella $\mathrm{L}$. & $\begin{array}{l}\text { zayacha kapusta, záyachy shchavyel', } \\
\text { zayach'ya kapusta, kislitsa }\end{array}$ & leaves & $\begin{array}{l}\text { raw children's snack, formerly sometimes used } \\
\text { for soups }\end{array}$ & [51], EP \\
\hline Pinus sylvestris $\mathrm{L}$. & sasná & resin(1), young shoots(2) & raw children's snack(1), famine food(2) & EP \\
\hline Plantago lanceolata $\mathrm{L}$. & n.d. & leaves & salads & EP \\
\hline Poa pratensis $\mathrm{L}$. & travka & young shoots & raw children's snack & EP \\
\hline $\begin{array}{l}\text { Polygonum bistorta L. (syn. Bistorta } \\
\text { major S. E. Gray) }\end{array}$ & PL: wężownik & leaves & eaten with bread during World War I & FS \\
\hline Prunella vulgaris L. (?) & PL: czemborek & aerial parts & infusion drunk as everyday drink & FS \\
\hline \multicolumn{5}{|l|}{$\begin{array}{l}\text { - uncertain identification, the folk } \\
\text { name suggests it could also be } \\
\text { Thymus sp. }\end{array}$} \\
\hline Prunus cerasifera Ehrh.* & alychá & fruits & fresh and in jams & $\mathrm{TG}, \mathrm{EP}$ \\
\hline Prunus spinosa L. & n.d. & fruits & spice for alcohol, raw snack & EP \\
\hline $\begin{array}{l}\text { Pulmonaria officinalis L. cf ssp. } \\
\text { obscura (Dumort.) Murb. (syn. } \\
\text { P. obscura Dumort.) }\end{array}$ & myedunitsa & flowers & $\begin{array}{l}\text { fresh nectar as a snack and made into herbal } \\
\text { teas }\end{array}$ & TG, EP \\
\hline Pyrus pyraster $\mathrm{L}$. & hróshka, hrúsha, ihrúshka, grusha lyesnáya & fruits & $\begin{array}{l}\text { raw or in boiled dishes, formerly fermented in } \\
\text { water and sugar }\end{array}$ & {$[17,51], \mathrm{TG}$} \\
\hline Quercus robur L. & dub & leaves and bark & formerly under baking bread & [51], EP \\
\hline Ribes nigrum L. & smoródina chyérnaya & fruits, twig and leaves & $\begin{array}{l}\text { fruits - fresh or dried; twigs - decoction; leaves } \\
\text { as spice for fermented sauerkraut, cucumbers } \\
\text { and tomatoes }\end{array}$ & $\mathrm{TG}, \mathrm{EP}$ \\
\hline Ribes uva-crispa $\mathrm{L}$. & kryzhóvnik & fruits & fresh & \\
\hline Robinia pseudoacacia L. & n.d. & flowers & formerly raw snack & EP \\
\hline Rosa canina L. and other spp. & shipóvnik sobáchyy & fruits & fresh and in jams, wine and herbal tea & TG, EP \\
\hline Rubus caesius L. & yezhevika & fruits & raw & EP \\
\hline Rubus chamaemorus L. & struzhýna & fruits & raw & [51] \\
\hline Rubus idaeus L. & malína & fruits & $\begin{array}{l}\text { fresh, jam, formerly dried as medicine inducing } \\
\text { sweating }\end{array}$ & {$[17,51], \mathrm{TG}, \mathrm{EP}$} \\
\hline Rubus saxatilis L. & kamyenítsa, kostyanika & fruits & raw & [17], EP \\
\hline Rubus subgenus Rubus & azhýna, ozhýna, stryzhýna & fruits & $\begin{array}{l}\text { mainly raw due to low abundance, sometimes } \\
\text { in wine and hot desserts }\end{array}$ & [17,51], EP \\
\hline Rumex acetosa L. & shchavyél', shchavyey & leaves & sour soup called borshch & {$[17,51], T G, E P, P A E$} \\
\hline Rumex acetosella $\mathrm{L}$. & verabyóvy shchavyél' & leaves & sour soup called borshch & [51] \\
\hline
\end{tabular}


Table 2 Contemporary use of wild food plants (20-21th century) (Continued)

\begin{tabular}{|c|c|c|c|c|}
\hline Rumex confertus Willd. & shchavyey & leaves & soup & EP \\
\hline Sambucus nigra L. & n.d. & fruit & juice, wines, rarely also raw & EP \\
\hline Sorbus aucuparia L. & ryabína, rabina & fruits & $\begin{array}{l}\text { mainly jam from frozen fruits, also raw as children's } \\
\text { snack and in herbal infusion or as spice }\end{array}$ & $\begin{array}{l}\text { TG, EP; according to [17] was } \\
\text { regarded as poisonous in Polesia }\end{array}$ \\
\hline Sorbus intermedia (Ehrh.) Pers. & n.d. & fruits & gathered from city greenery in Minsk for preserves & TG \\
\hline Stellaria media (L.) Vill. & zvyezdchátka, makritsa & leaves & fresh in salads, squeezed into juice & TG \\
\hline Syringa vulgaris $L .{ }^{*}$ & siryen' $^{\prime}$ & nectar from flowers & raw children's snack & EP \\
\hline Taraxacum sp. & n.d. & $\begin{array}{l}\text { nectar from flowers, } \\
\text { leaves }\end{array}$ & raw snack, leaves also in salads & EP \\
\hline Thymus spp. & n.d. & flowering tops & herbal infusion, spice for alcohol & EP \\
\hline Tilia cordata Mill. & lípa & flowers, leaves & $\begin{array}{l}\text { nectar and leaves as children's snack, infusion from } \\
\text { flowers as beverage }\end{array}$ & TG, EP \\
\hline Trifolium spp., mainly T. pratense L. & klyevyer, trilistnik & nectar from flowers & raw children's snack & EP \\
\hline Urtica dioica L. and U. urens $\mathrm{L}$. & krapiva, PL: pokrzywa & aerial parts & potherb, now rarely; formerly also sour soups & [51], EP, FS \\
\hline Vaccinium myrtillus L. & chernítsa, charnítsa, chyerníka, & fruits and leaves & $\begin{array}{l}\text { fruits- fresh, jams and juice, or in milk soups, leaves } \\
\text { as spice for fermented sauerkraut, cucumbers and } \\
\text { tomatoes; the most widely gathered wild fruits } \\
\text { in Belarus }\end{array}$ & {$[17,51], T G, E P, P A E$} \\
\hline Vaccinium oxycoccos L. & klyúkva, klukva, zhuravína & fruits & $\begin{array}{l}\text { fresh, jam, kisel, juice, formerly also added to } \\
\text { suaerkraut }\end{array}$ & {$[17,51]$, TG, EP. PAE } \\
\hline Vaccinium uliginosum $\mathrm{L}$. & lohynya, buyakí, golubika; PL: pijanica & fruits & raw, in many places considered inedible & [51], EP \\
\hline Vaccinium vitis-idaea $\mathrm{L}$. & brushnítsa, brus'nítsa, brusnika & fruits & raw or jam & {$[17,51]$, EP, PAE } \\
\hline Viburnum opulus L. & kalína & fruits & jams, boiled in kisyel', raw - after drying & {$[17,51], \mathrm{TG}$} \\
\hline Viola tricolor $\mathrm{L}$. & n.d. & aerial parts & herbal tea & EP \\
\hline
\end{tabular}

* a non-native cultivated species also collected from the populations escaped from cultivation. EP Ewa Pirożnikow's questionnaires from Belarusian respondents (mainly botanists); TG Tanya Gervasi's field interviews; PAE Data from the Polish Ethnographic Atlas - retrospectives of Poles resettled from Belarus in
the 1940s; FS Adam Fischer's archives (Polish Folklorist Society, Wrocław). 
Table 3 Wild food plants used in Belarus according to Rostafiński's respondents

\begin{tabular}{|c|c|c|c|c|c|c|}
\hline Scientific name & Rel. & $\begin{array}{l}\text { Local name in 19th c. } \\
\text { Names used by Poles } \\
\text { marked with PL }\end{array}$ & Part used & Use & Vo. & Letter $* * *$ \\
\hline Acer platanoides $\mathrm{L}$. & $\mathrm{H}$ & klon & sap & fresh or added to sour soups & 50 & FED, WOJ \\
\hline Acorus calamus L. & L & ajer, tatarak & leaves & $\begin{array}{l}\text { leaves added under baking bread } \\
\text { (which was supposed to have } \\
\text { carminative properties as well) }\end{array}$ & & LAS \\
\hline Aegopodium podagraria L. & $\mathrm{H}$ & $\begin{array}{l}\text { śnitka, snitka, sznitka, śniatka, } \\
\text { PL: śnitka }\end{array}$ & aerial parts & $\begin{array}{l}\text { soups, sour and non-sour, potherb, } \\
\text { rarely dried for winter use }\end{array}$ & 4 & $\begin{array}{l}\text { CZA, DYB, FED, KOR, LAS, LES, } \\
\text { NAR, OSS, SLO, TWA, WOJ }\end{array}$ \\
\hline Allium sp.? & $\mathrm{N}$ & PL: czosnek dziki & n.d. & n.d. & & LAS \\
\hline Anchusa arvensis (L.) M.Bieb. & $\mathrm{H}$ & padasocik, PL: podosocik & aerial parts & non-sour soups & 11 & FED \\
\hline Anethum graveolens L. (?) & $\mathrm{N}$ & kopr & aerial parts & spice & & LES \\
\hline $\begin{array}{l}\text { Armoracia rusticana G.Gaertn., } \\
\text { B.Mey. \& Schreb }\end{array}$ & $\mathrm{O}$ & chrin, PL: chrzan & n.d. & $\begin{array}{l}\text { so obvious that use not given, only } \\
\text { one author wrote about salad with vinegar }\end{array}$ & & (LAS, LES, NAR, NIE, OSS, TWA,WOJ) \\
\hline Berberis vulgaris $\mathrm{L}$. & $\mathrm{N}$ & berberys (also PL) & fruits & raw & & FED \\
\hline Betula spp. & $\mathrm{H}$ & bereza, bieroza, PL: brzoza & sap & $\begin{array}{l}\text { fresh, added to sour soups, fermented } \\
\text { into a refreshing drink with dried apples, } \\
\text { bread rinds and oak bark, or sugar }\end{array}$ & 45 & FED, NIE, WOJ \\
\hline Carum carvi L. & L & kmin & fruits & $\begin{array}{l}\text { spice for bread, sauerkraut, fresh } \\
\text { cheese, spirits }\end{array}$ & & $\begin{array}{l}\text { CZA, DYB, FED, OSS, SLO, WOJ, } \\
(\text { (LAS, ONU) }\end{array}$ \\
\hline Centaurea cyanus L. & $\mathrm{H}$ & $\begin{array}{l}\text { wałoszka, PL: wołoszka, } \\
\text { włoszka, bławatki }\end{array}$ & $\begin{array}{l}\text { very } \\
\text { young } \\
\text { shoots }\end{array}$ & non-sour soups & 9 & FED, KOR \\
\hline Chenopodium album $\mathrm{L}$. & $\mathrm{H}$ & lebieda, PL: lebioda & aerial parts & non-sour soups, dried for winter use & 14 & FED, KOR, CZA, ONU, OSS, WOJ, (TWA) \\
\hline Cirisum arvense (L.) Scop. & $\mathrm{H}$ & asot, PL: oset & aerial parts & non-sour soups & 10 & FED \\
\hline Convolvulus arvenis L. & $\mathrm{H}$ & bierozka,PL: bierozka, brzózka & aerial parts & non-sour soups & 7 & FED \\
\hline Corylus avellana $\mathrm{L}$. & $\mathrm{H}$ & $\begin{array}{l}\text { harieszyna; PL: orzechy, } \\
\text { orzeszyna, leszczyna }\end{array}$ & fruits & n.d. & 48 & FED, LAS \\
\hline Fallopia convolvulus (L.) Á.Löve & $\mathrm{H}$ & podbierozka (also PL) & aerial parts & non-sour soups & 8 & FED \\
\hline Fragaria spp., mainly $F$. vesca $L$. & $\mathrm{H}$ & $\begin{array}{l}\text { sunicy, paziomki, poziemi, } \\
\text { sunyca, PL: poziomki }\end{array}$ & fruits & raw & 26 & FED, OSS, (LAS, NIE, WOJ) \\
\hline $\begin{array}{l}\text { Glyceria fluitans (L.) R.Br. and } \\
\text { most likely other related } \\
\text { Glyceria species } \\
\text { (in the letters as Glyceria and } \\
\text { Glyceria fluitans) }\end{array}$ & L & manna (also PL), majńo & grains & $\begin{array}{l}\text { made into groat (kasha), mainly boiled in } \\
\text { milk, sold in the market of Pińsk, in many } \\
\text { places stopped being used in the } \\
\text { 1850-60s }\end{array}$ & & FED, LAS, NIE, ONU, OSS, SLO, TWA, WOJ \\
\hline Helianthus tuberosus L.* & $\mathrm{N} / \mathrm{D}$ & bulba, bulwa & bulbs & $\begin{array}{l}\text { roasted or fried, mainly planted } \\
\text { but one report says that it was } \\
\text { very persistent and "self-sowing" }\end{array}$ & & (DYB, NAR, ONU, TWA, WOJ) \\
\hline
\end{tabular}


Table 3 Wild food plants used in Belarus according to Rostafiński's respondents (Continued)

\begin{tabular}{|c|c|c|c|c|c|c|}
\hline Heracleum sphondylium L. & $\mathrm{H}$ & $\begin{array}{l}\text { borszcz, barszcz, barszczewnik, } \\
\text { PL: borszcz, barszcz }\end{array}$ & & $\begin{array}{l}\text { sour soups, potherb, often } \\
\text { dried for winter }\end{array}$ & 19 & CZA, DYB, FED, OSS, SLO, TWA, (LAS) \\
\hline Lamium sp. or Pulmonaria sp.? & $\mathrm{N}$ & miedunka & aerial parts & potherb & & CZA \\
\hline Nymphaea alba L. & $\mathrm{L}$ & [grzybienie] & seeds & n.d. & & NIE \\
\hline Oxalis acetosella $\mathrm{L}$. & $\mathrm{H}$ & $\begin{array}{l}\text { zazulin szczawiej, PL: szczaw } \\
\text { kukawki, szczaw zajęczy }\end{array}$ & leaves & sour soups & 17 & FED, (WOY) \\
\hline Papaver somniferum L.* & L & samosiejka, widuk & seeds & $\begin{array}{l}\text { "for ordinary use ", i.e. bread } \\
\text { and sweets }\end{array}$ & - & DYB \\
\hline Plantago major L. & $\mathrm{H}$ & babka (also PL) & leaves & non-sour soups & 6 & FED2 \\
\hline Plantago sp. & $\mathrm{L}$ & tryputnik & leaves & sour soups, potherb & & OSS, SLO \\
\hline $\begin{array}{l}\text { Polygonum aviculare L. or } \\
\text { Plantago major L.? }\end{array}$ & N & podorożnik & aerial parts & sour soup & & OSS \\
\hline $\begin{array}{l}\text { Polygonum bistorta L. (syn. } \\
\text { Bistorta major S. E. Gray) }\end{array}$ & $\mathrm{H}$ & $\begin{array}{l}\text { oborocień, obaracień, oberek, } \\
\text { ober, PL: ober }\end{array}$ & $\begin{array}{l}\text { leaves, } \\
\text { seeds }\end{array}$ & $\begin{array}{l}\text { sour soup, seeds for flatbread, } \\
\text { particularly in the } 1855 \text { famine }\end{array}$ & 2 & DYB, FED \\
\hline Prunus padus L. & $\mathrm{O}$ & $\begin{array}{l}\text { czeremcha czeremszyna, } \\
\text { czeromcha, PL: czeremcha }\end{array}$ & fruits & n.d. & $23^{* *}$ & FED \\
\hline Prunus spinosa L. & L & PL: tarnina & fruits & n.d. & & $(\mathrm{LAS})$ \\
\hline Pteridium aquilinum (L.) Kuhn & $\mathrm{H}$ & $\begin{array}{l}\text { paporocień, paporotnik, PL: } \\
\text { paproć }\end{array}$ & rhizomes & $\begin{array}{l}\text { dried, ground and mixed with } \\
\text { ordinary flour to make bread }\end{array}$ & 1 & FED2 \\
\hline Pyrus pyraster L. & $L$ & PL: gruszki dziczki & fruits & raw and conserved & & ONU \\
\hline Quercus robur L. & $\mathrm{O}$ & dub & leaves & $\begin{array}{l}\text { under baking bread (added also due } \\
\text { to its carminative properties as well) }\end{array}$ & & LAS \\
\hline Ranunculus repens $\mathrm{L}$. & $\mathrm{H}$ & padśnitnik, PL: podśnitnik & & non-sour soups & 5 & FED \\
\hline Raphanus raphanistrum $\mathrm{L}$. & A & swierzepa, sweripa, świrzepa & leaves & soups, potherb & & NIE, TWA \\
\hline Ribes nigrum L. & N & $\begin{array}{l}\text { smrodziny, smorodinka, } \\
\text { smrodyna, PL: smrodziny, } \\
\text { czarne porzeczki }\end{array}$ & $\begin{array}{l}\text { fruits, } \\
\text { leaves }\end{array}$ & $\begin{array}{l}\text { fruits raw, leaves used in manors to } \\
\text { make a fizzy drink and to make } \\
\text { vodka taste "older" (NIE) }\end{array}$ & & FED, NIE, WOJ, (LAS) \\
\hline Ribes spicatum Robson & $\mathrm{N} / \mathrm{R}$ & parieczki, PL: porzeczki & fruits & raw & & FED \\
\hline Ribes uva-crispa L. & $L$ & jagrest, PL: agrest & fruits & raw & & FED \\
\hline Rosa sp. & O & PL: róża & flowers & $\begin{array}{l}\text { formerly fried in batter, in a Polish } \\
\text { manor, rare }\end{array}$ & & SLO \\
\hline Rubus idaeus L. & $\mathrm{O}$ & maliny (also PL), małyna & fruits & raw & & FED, OSS, WOJ, (LAS, NIE) \\
\hline Rubus nessensis W.Hall & $\mathrm{D} / \mathrm{R}$ & jaryna & fruits & raw & & WOJ \\
\hline Rubus saxatilis L. & $\mathrm{H}$ & kościanicy, PL: kościanki & fruits & raw & 28 & FED \\
\hline $\begin{array}{l}\text { Rubus subgenus Rubus } \\
\text { (probably mainly Rubus } \\
\text { plicatus L., R. nessensis } \\
\text { W.Hall and R. caesius L.) }\end{array}$ & $\mathrm{H}$ & $\begin{array}{l}\text { ażyny, czornyje maliny, } \\
\text { ożyna, PL: ożyny }\end{array}$ & fruits & raw & 24 & FED, WOJ, (NIE, LAS) \\
\hline
\end{tabular}


Table 3 Wild food plants used in Belarus according to Rostafiński's respondents (Continued)

\begin{tabular}{|c|c|c|c|c|c|c|}
\hline Rumex acetosa $\mathrm{L}$. & $\mathrm{H}$ & szczawiej, PL: szczaw & leaves & sour soups & 16 & FED \\
\hline Rumex crispus L. & $\mathrm{H}$ & karpacz (also PL) & leaves & sour soups & 20 & FED \\
\hline $\begin{array}{l}\text { Rumex sp. (probably mainly } \\
\text { R. acetosa L.) }\end{array}$ & & szczaw, szczawel & $\begin{array}{l}\text { leaves and } \\
\text { stalks }\end{array}$ & $\begin{array}{l}\text { raw and in sour soups, as OSS } \\
\text { put: "with kvas, whey, sweet or } \\
\text { sour milk, butter milk, cream or } \\
\text { pig fat (slonina) with vinegar" }\end{array}$ & & NIE, OSS, ONU, SLO, (CZA) \\
\hline Rumex thyrsiflorus Fing. & $\mathrm{H}$ & harabiniec, PL: szczaw polny & leaves & sour soups & 18 & FED \\
\hline Sambucus nigra L. & $\mathrm{N}$ & PL: bez & flowers & $\begin{array}{l}\text { formerly fried in batter, in a } \\
\text { Polish manor, rare }\end{array}$ & & SLO \\
\hline Scirpus lacustris L. & L & [sitowie] & $\begin{array}{l}\text { young } \\
\text { stalks }\end{array}$ & raw & & $\mathrm{NIE}$ \\
\hline Silene vulgaris (Moecnch)Garcke & $\mathrm{H}$ & laskouka,PL: laskówka & aerial parts & $\begin{array}{l}\text { non-sour soups, dried for } \\
\text { winter use }\end{array}$ & 12 & FED \\
\hline Silene vulgaris (?) & N & łuskawka & aerial parts & potherb & & $\mathrm{KOR}$ \\
\hline Sinapis arvensis $\mathrm{L}$. & $\mathrm{H}$ & $\begin{array}{l}\text { redźkouka, świerepa, PL: } \\
\text { świrepa, świerżop }\end{array}$ & & $\begin{array}{l}\text { non-sour soups, dried for } \\
\text { winter use }\end{array}$ & 15 & FED \\
\hline $\begin{array}{l}\text { Sinapis arvensis L. or Raphanus } \\
\text { raphanistrum L. }\end{array}$ & N & świrzepa & leaves & soup or with kasha & & ONU, (TWA) \\
\hline Sorbus aucuparia L. & $\mathrm{N}$ & PL: jarzębina & fruits & raw after freezing & & CZA \\
\hline Stellaria media (L.) Vill. & $\mathrm{H}$ & makryca bieła, PL: mokrzyca biała & aerial parts & $\begin{array}{l}\text { non-sour soups, dried for } \\
\text { winter use }\end{array}$ & $62^{* * *}$ & FED \\
\hline Trapa natans L. & L & PL: orzechy wodne & seeds & raw and boiled & & NIE \\
\hline $\begin{array}{l}\text { Urtica spp. (3 records confirm U. } \\
\text { dioica L. and } 4 \text { rec. - U. urens L.) }\end{array}$ & $\mathrm{H}$ & $\begin{array}{l}\text { krapiwa, kropiwa, kropywa, } \\
\text { życzka, żyszka, żyżka, prokywa, } \\
\text { prokiwa, pokrzywka, } \\
\text { krapiwa piekuszcza, U. urens } \\
\text { also rzeszka, rzyczkaja krapiwa; } \\
\text { PL: rzeszka, pokrzywa, } \\
\text { U. urens also: żagawka, } \\
\text { żegawka, rzeszka }\end{array}$ & aerial parts & non-sour and sour soups & U. urens - 3 & $\begin{array}{l}\text { CZA, DYB, FED, LAS, LES, NAR, } \\
\text { ONU, OSS, TWA, WOJ, (SLO) }\end{array}$ \\
\hline Vaccinium myrtillus L. & L/O & $\begin{array}{l}\text { czarnica, czernyca, czernica, } \\
\text { czarnicy, czornyje } \\
\text { jahody, czerniec; PL: czernice, } \\
\text { czarne jagody }\end{array}$ & fruits & $\begin{array}{l}\text { raw, commonly dried; also } \\
\text { boiled with milk into a kind of soup }\end{array}$ & 27 & DYB, FED, OSS, NIE, WOJ, (LAS) \\
\hline Vaccinium oxycoccos L. & $\mathrm{L} / \mathrm{O}$ & $\begin{array}{l}\text { żurauliny, żurachwyna, PL: } \\
\text { żurawiny, żórawiny }\end{array}$ & fruits & $\begin{array}{l}\text { raw, stored for months in water, in } \\
\text { manors made into kissel (with } \\
\text { potato flour) }\end{array}$ & & DYB, FED, OSS, NIE, WOJ, (LAS) \\
\hline Vaccinium uliginosum $\mathrm{L}$. & $\mathrm{L} / \mathrm{O}$ & $\begin{array}{l}\text { durnicy, bałabony, łochwaczi, } \\
\text { PL: durnice }\end{array}$ & fruits & raw & & $\begin{array}{l}\text { FED, FED2, NIE, (LAS), whereas } \\
\text { WOJ says that it is narcotic }\end{array}$ \\
\hline Vaccinium vitis-idaea $\mathrm{L}$. & $\mathrm{L} / \mathrm{O}$ & $\begin{array}{l}\text { brusznicy (also PL), bruśnica, } \\
\text { brusznyca }\end{array}$ & fruits & $\begin{array}{l}\text { raw, in manors made into } \\
\text { jams and pickles }\end{array}$ & 25 & FED, OSS, WOJ, (DYB, LAS, NIE) \\
\hline Veronica cf persica Poiret & $\mathrm{H}$ & $\begin{array}{l}\text { makryca bieła, PL: mokrzyca } \\
\text { biała }\end{array}$ & aerial parts & $\begin{array}{l}\text { non-sour soups, dried } \\
\text { for winter use }\end{array}$ & $13,62^{* * *}$ & FED \\
\hline
\end{tabular}


Table 3 Wild food plants used in Belarus according to Rostafiński's respondents (Continued)

\begin{tabular}{lllll}
\hline Viola cf odorata L. & $N$ & PL: fiołki & flowers & $\begin{array}{l}\text { formerly fried in batter, in a } \\
\text { Polish manor, rare }\end{array}$ \\
\hline$?$ & mirsik & aerial parts & soups & SLO \\
\hline$?$ & mrzyk & aerial parts & soups & SLO \\
\hline$?$ & opich & aerial parts & soups & SLO \\
\hline$?$ & $\begin{array}{l}\text { saładucha, smaktucha, PL: } \\
\text { sołoducha }\end{array}$ & aerial parts & non-sour soups & FED \\
\hline & zieziulina sałata & aerial parts & raw as salad (like lettuce) & FED \\
\hline
\end{tabular}

Rel. Reliability of identification (after [2]): $H$ Confirmed by voucher specimen; $O$ Obvious common name universally used over a large area; $L$ Probable Latin name or scientific name used in the language of a given country, given by a non-botanist; $N$ Determined using comparative analysis of folk names; $R$ determined with the help of the data of a species range or/and habitat; $D$ determined with the help of the verbal description.

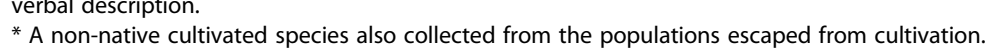

** The voucher specimen belongs to Euonymus europaea L., an obvious mistake.

*** The nam

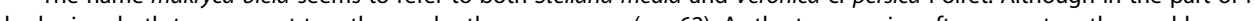
herbarium both taxa are put together under the same na that both taxa were probably used.

fine

Vo Voucher specimen number given by Federowski. 
pounded in a wooden mortar and mixed with rye flour into ordinary grain dishes.

Out of the species in the 19th century only 32 species have been reported as used in 20th or 21st century studies. In these modern studies, however, new plant taxa are reported as used, mainly children's snacks or alien species of fruits. Altogether, we collected data on the culinary use of 67 taxa in the 20th and 21st centuries (Table 2, 3), which gives 93 edible taxa recorded at some point between 1883 and the present.

\section{Discussion}

We can assume that only some of the plants used in Belarus in the 19th century are used nowadays. For example, using Pteridium aquilinum rhizomes and Polygonum bistorta seeds as staples was already a curiosity by the end of the 19th century. Also the reported wide use of wild green vegetables has immensely decreased in Belarus, with the exception of the use of Rumex spp. to make a kind of sour soup, still an important part of Belarusian cuisine. Thus, a process similar to other eastern European countries has occurred in Belarus, where the use of most wild greens has ceased [6-12,57] and the main edible plants used or remembered are fruits and children's snacks (compare [6,58]). Also, in contemporary internet culinary forums in Belarus, fruits are the dominant wild food category mentioned. The use of wild vegetables has decreased (Figure 3) in a similar manner among the Belarusian minority in NE Poland investigated by one of the co-authors of this article (E.P.), where many of the plants listed in this study are remembered mainly as old-time poverty food (e.g. Urtica spp., Chenopodium album, Aegopodium podagraria etc.).

Pietkiewicz, in his 1928 ethnographic monograph of a part of Polesia, mentioned only Urtica, Rumex, Oxalis and Atriplex (mistakenly for Chenopodium) as wild green vegetables used in food [51], whereas Moszyński, also in 1928 [17] did not even mention the use of any other greens apart from Rumex, although Rostafiński's respondents, only 40 years before, mentioned more species used in that area.

The resilience of sorrel in Belarusian and other north and eastern European cuisines [6-12], i.e. the fact that it is still widely used, while other wild greens have declined so much, is mysterious. The most likely explanation is that it is appreciated due to its sour taste and smooth texture. The sour taste has been highly appreciated in traditional eastern European cuisines and most sour foods are produced by lactic fermentation of pickling. Thus sorrel's sour taste may have automatically placed it in the human realm of transformed food, even before it was cooked. Paraphrasing Lévi-Strauss's division [59], instead of Raw versus Cooked (in the French original cru and cuit), we could say Raw versus Cooked/Sour. By belonging to the Sour/Cooked domain, sorrel was singled out from other wild vegetables.

The resilience of the contemporary use of wild fruits such as Rubus idaeus, Vaccinium spp. and Viburnum opulus in Belarus may be explained by cultural attachment to these species, which are perceived as "very healthy". Selling Viburnum opulus fruits, for example, at the open markets of Minsk in September is still very popular, and most of the sellers and customers ascribed to the berries - which are sometime also consumed raw, as snacks - important preventative properties. In the 19th century Viburnum was not even reported as wild food, but rather as medicine. This reinforces the findings that the permanence of Traditional Plant Knowledge in the context of cultural changes may be directly related to the success of certain food plants, which are perceived as food-medicines, as, for example, other contemporary field ethnobotanical studies among migrants have demonstrated $[60,61]$.

The differences between the species eaten in the 19th century (Table 2) and contemporary uses (Table 3) do not only arise from the fact that the use of some species has ceased. Some species listed nowadays may have been used in the 19th century but the amount of observations (only from 13 respondents) was not enough to capture it. Also, the structure of Rostafiński's questionnaire was very specific, he pre-suggested certain taxa, which he was particularly interested in, which may have slightly biased the information given. Children's snacks reported in the contemporary data must have been collected in the 19th century, but were not recorded then. A similar situation occurred in Poland, when a questionnaire among botanists revealed a long list of minor children's snacks, never noted before [62].

The commonness of drying wild vegetables for winter use in soups, observed by Federowski, is worth noting. Drying wild greens for human use as a preservation technique occurs in parts of China (see e.g. [63]) but has not been observed in Europe. The fact that these plants were preserved suggests that they had a high cultural status. It is even more puzzling, then, that their presence in contemporary Belarusian cuisine is so reduced.

Of course, it is possible that more in-depth studies in rural Belarus would confirm the survival of some uses. Moreover, a noteworthy phenomenon is the gathering of several recently established non-native taxa. Edible fruits such as Hippophaë rhamnoides, Prunus cerasifera and Sorbus intermedia, which are cultivated, are also gathered from wild locations (i. e. as garden escapees) or from populations planted as a part of town greenery. Also Rumex confertus is a recently spreading large-leaved sorrel species incorporated into cuisine, like native Rumex species.

As the use of wild vegetables was more common in Belarus in the 19th century than in Poland as observed 


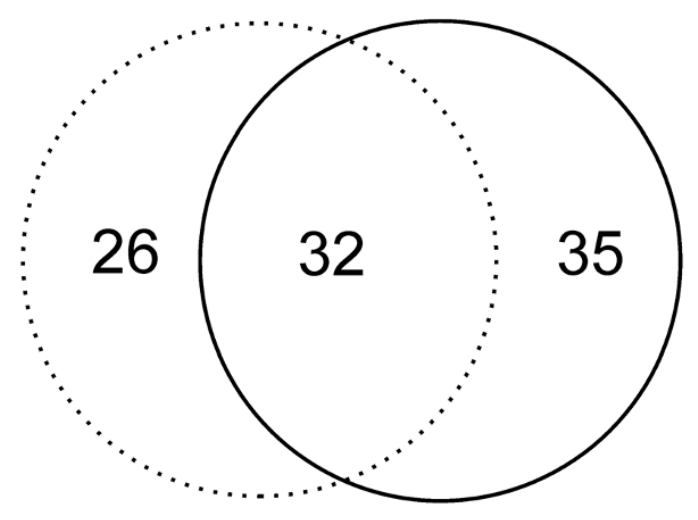

ALL SPECIES

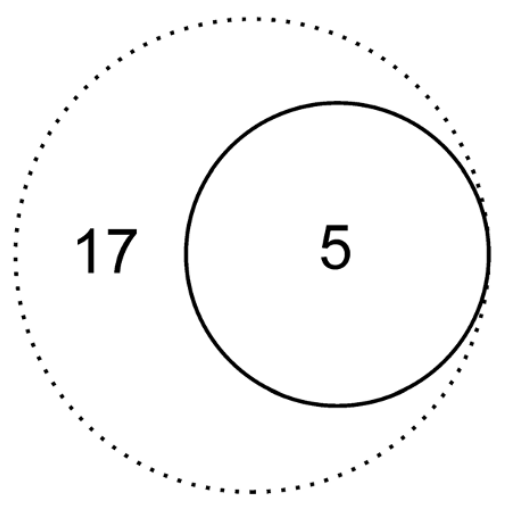

\section{WILD GREENS IN SOUPS (botanical genera)}

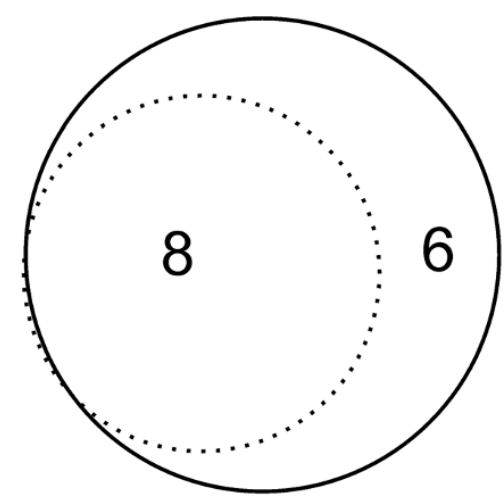

\section{FLESHY FRUITS (botanical genera)}

Figure 3 The relationships between the taxa recorded in Rostafiński's questionnaire from 1883 (dotted line) and the 20th and 21 st century data (solid line): while the number of wild greens genera used in soups decreased, the number of wild fruit genera used in nutrition increased. by Moszyński, Federowski and a few other ethnographers, we can assume that even now we may find more vestiges of traditional plant use in this country, making it a promising arena for future ethnobotanical studies. Here we point out just a few of the ethnobotanical phenomena in Belarus which should be studied in detail:

- The strong tradition of fermented dishes made from both cultivated plants like cucumbers, cabbage or tomatoes, as well as wild ingredients, e.g. mushrooms (mainly Lactarius spp.), birch sap or wild plants used as spices for fermentation (e.g. Quercus robur leaves, Ribes nigrum leaves);

- The role of tree sap in traditional culture - as Belarus is the only country in Europe where the collection of tree sap is regulated by the state [43] and is extremely popular there;

- The culinary use of marsh and water plants in the wetlands of Polesia (in the 19th century the use of Scirpus lacustris, Trapa natans and Nymphea alba was recorded in this area);

- The level of preservation of the use of wild green vegetables.

The recorded wild food plant taxa constitute $5 \%$ of the country's flora. It is lower than for Hungary - 7\% [10], Estonia - 6\% [9] and Poland - 5.5\% [8] but higher than Slovakia - 3.5\% [12]. However, the amount of data available from Belarus is lower than from the first three countries, which means that several taxa with minor importance in traditional nutrition could be yet to be discovered. The general structure of various use categories and the sequence of their disappearance from the contemporary diet, as well as some culinary vogues (like jam- making, in the 20th century) are astoundingly similar to those reported from other northern and eastern European countries [5-12,58].

\section{Conclusions}

The responses to Rostafiński's questionnaire from 1883 present extremely valuable historical material as the use of wild food plants in Belarus has since undergone drastic changes, similar to those, which have taken place in other Eastern European countries. Although most taxa reported in this study have been used in other Slavic countries, the local food culture preserved, at least up to the early 20th century, many archaic features, e.g. the wide use of lacto-fermented wild food plants, drying wild vegetables for winter etc. Further studies on the level of preservation of the uses of plants reported by Rostafiński's respondents are needed.

\section{Competing interests}

The author's declare that they have no competing interest. 


\section{Authors' contributions}

All the authors took part in writing the paper, additionally $Ł$ : initiated and coordinated the study and wrote the first version of the paper; PK: analyzed the history of Rostafiński's questionnaire and, together with $Ł$, analyzed its content; MG: found Federowski's questionnaires and provided literature on Federowski's studies; EP, TG and AP provided field data on contemporary plant use in Belarus. All authors read and approved the final manuscript.

\section{Acknowledgments}

We are grateful to Prof. Krzysztof Oklejewicz (University of Rzeszów) for his help in identifying some herbarium specimens.

\section{Author details}

'Institute of Applied Biotechnology and Basic Sciences, Department of Botany and Biotechnology of Economic Plants, University of Rzeszów, Werynia 502, 36-100 Kolbuszowa, Poland. Institute of Botany, The Jagiellonian University, ul. Kopernika 27, 31-501 Kraków, Poland. ${ }^{3}$ Department of Botany, Institute of Biology, University of Białystok, ul. Świerkowa 20B, 15-950 Białystok, Poland. ${ }^{4}$ Herbarium of the Institute of Botany of the University of Warsaw, University of Warsaw, Al. Ujazdowskie 4, 00-478 Warszawa, Poland. ${ }^{5}$ University of Gastronomic Sciences, Piazza Vittorio Emanuele 9, I-12060 Bra/Pollenzo, Cuneo, Italy.

Received: 13 February 2013 Accepted: 16 March 2013

Published: 4 April 2013

\section{Reference}

1. Mavengahama S, McLachlan M, de Clercq W: The role of wild vegetable species in household food security in maize based subsistence cropping systems. Food Sec 2013. doi:10.1007/s12571-013-0243-2. in press.

2. Legwaila GM, Mojeremane W, Madisa ME, Mmolotsi RM, Rampart M: Potential of traditional food plants in rural household food security in Botswana. J Hortic Forest 2011, 3(6):171-177.

3. Shresta PM, Dhillion SS: Diversity and traditional knowledge concerning wild food species in a locally managed forest in Nepal. Agroforest Syst 2006, 66(1):55-63.

4. Bharucha Z, Pretty J: The roles and values of wild foods in agricultural systems. Phil Trans R Soc B 2010, 365:2913-2926.

5. Turner NJ, Łuczaj $Ł$, Migliorini P, Pieroni A, Dreon AL, Sacchetti L, Paoletti MG: Edible and tended wild plants, traditional ecological knowledge and agroecology. Cr Rev Plant Sci 2011, 30:198-225.

6. Łuczaj Ł, Szymański WM: Wild vascular plants gathered for consumption in the Polish countryside: a review. J Ethnobiol Ethnomed 2007, 3:17.

7. Łuczaj Ł: Plant identification credibility in ethnobotany: a closer look at Polish ethnographic studies. J Ethnobiol Ethnomed 2010, 6:36.

8. Łuczaj $Ł$ : Changes in the utilization of wild green vegetables in Poland since the 19th century: a comparison of four ethnobotanical surveys. J Ethnopharmacol 2010, 128:395-404.

9. Kalle R, Sõukand R: Historical ethnobotanical review of wild edible plants of Estonia (1770 s-1960s). Acta Soc Bot Pol 2012, 81(4):271-281.

10. Dénes A, Papp N, Babai D, Czúcz B, Molnár Z: Wild plants used for food by Hungarian ethnic groups living in the Carpathian Basin. Acta Soc Bot Pol 2012, 81(4):381-396.

11. Svanberg I: The use of wild plants as food in pre-industrial Sweden. Acta Soc Bot Pol 2012, 81(4):317-327.

12. Łuczaj $Ł$ : Ethnobotanical review of wild edible plants of Slovakia. Acta Soc Bot Pol 2012, 81(4):381-396.

13. Anonymous: Belarus: Country Report to the FAO. International Technical Conference on Plant Genetic Resource (Leipzig, 1996). Minsk: Research Insitute of Agriculture and Forages; 1995. http://www.fao.org/fileadmin/templates/ agphome/documents/PGR/SoW1/Europe/BELARUS.pdf.

14. Moszyński K: O sposobach badania kultury materialnej Prasłowian. Wrocław: Zakład Narodowy im. Ossolińskich; 1962.

15. Moszyński K: Kultura ludowa Słowian. Kraków: Polska Akademia Umiejętności. 1929-1939.

16. Makhnach Al: Etnahrafichnyya ekspedytsyi K. Mashynskaha na Belarusi. Pratsy histarychnaha fakul'teta BDU: navuk. zb. 4. Працы гістарычнага факультэта БДУ: навук. 3б. Вып 2009, 4:301-308.

17. Moszyński K: Polesie wschodnie, materjały etnograficzne z wschodniej częšci b. powiatu mosyrskiego oraz z powiatu rzeczyckiego. Kasa Mianowskiego: Warszawa; 1928.
18. Federowski M: Lud Białoruski na Rusi Litewskiej. Materyały do etnografii słowiańskiej zgromadzone w latach 1877-1891. Tom 1. Wiara, wierzenia i przesady ludu z okolic Wołkowyska, Słonima, Lidy i Sokółki. Kraków: Polska Akademia Umiejętności; 1897.

19. Orzeszkowa E: Ludzie i kwiaty nad Niemnem. Wisła 1888, 2:1-15.

20. Orzeszkowa E: Ludzie i kwiaty nad Niemnem. Wisła 1888, 2:675-703.

21. Orzeszkowa E: Ludzie i kwiaty nad Niemnem. Wisła 1890, 4:1-31.

22. Orzeszkowa E: Ludzie i kwiaty nad Niemnem. Wisła 1891, 5:235-247.

23. Spólnik A: Z historii i geografii nazw roślin (na przykładzie Nad Niemnem Elizy Orzeszkowej). Rocznik Naukowo-Dydaktyczny WSP w Krakowie 192 Prace Językoznawcze 1997, 9:239-248.

24. Kielak AM: Zielnik Elizy Orzeszkowej. Nieznany zabytek botaniczny przechowywany w zbiorach Poznańskiego Towarzystwa Przyjaciół Nauk. Poznań: Wydawnictwo Kontekst; 2004

25. Kielak AM: O kresomym zielniku Elizy Orzeszkowej. Warszawa-Lida: Retro-Art; 2005.

26. Kuźnicka B: Zielniki i albumy florystyczne Elizy Orzeszkowej. Kwart Hist Nauki Tech 2006, 51(3):69-78.

27. Tishenki E: Botaniczna działalność Elizy Orzeszkowej w Grodnie. Analecto 2007, 16(1/2):65-68.

28. Kielak AM: Eliza Orzeszkowa - znawczyni sztuki zielarskiej. Analecta 2007, 16(1/2):55-64.

29. Czurak M: Rośliny lecznicze w zbiorze Lud Białoruski Michała Federowskiego. Acta Baltico-Slavica 2004, 28:271-277.

30. Szcześniak K: Białoruskie nazwy roślin w słowniczku Zośki Wieras. Łódź: Dialektologia jako dziedzina językoznawstwa i przedmiot dydaktyki: księga jubileuszowa dedykowana profesorowi Karolowi Dejnie; 2002:509-515.

31. Köhler PS, Piekiełko-Zemanek A: Józefa Rostafińskiego odezwa do nie botaników o zbieranie ludowych nazw roślin i udział w niej Marii Twardowskiej. Kwart Hist Nauki Tech 1986, 31(2):471-480.

32. Köhler P: Józefa Rostafińskiego "Odezwa do nie botaników o zbieranie ludowych nazw roślin". Wszechświat 1986, 87(1):13-16.

33. Zemanek A: Józef Rostafiński: botanik i humanista. Kraków: Polska Akademia Umiejętności; 2000.

34. Köhler PS: Nieznane materiały Józefa Rostafińskiego do badań nad historią roślin uprawnych w Polsce. Unknown material of Józef Rostafiński concerning studies of the history of cultivated plants in Poland. Zeszyty Naukowe Uniwersytetu Jagiellońskiego Prace Botaniczne 1987, 14:141-154.

35. Köhler P: Ankieta Józefa Rostafińskiego z 1883 roku dotycząca ludowego nazewnictwa roślin w Polsce. Analecta - Studia z Dziejów Nauki i Techniki 1993, 2:89-119.

36. Łuczaj $Ł$ : Dziko rosnące rośliny jadalne $w$ ankiecie Józefa Rostafińskiego $z$ roku 1883. Wiadomości Botaniczne 2008, 52(1/2):39-50.

37. Belarus. http://en.wikipedia.org/wiki/Belarus.

38. BELTUR.BY Internet-portal Otdyh $\vee$ Belarusi. http://www.beltur.by/? Flora_Belarusi.

39. Zaprudnik J: Belarus at a Crossroads in History. San Francisco: Westview Press; 1993.

40. Goldenkov M: Rus': drugaya istoriya. Minsk: Bukmaster; 2011.

41. Gelin DL, Bolotnikova VA, Domoratskaya LC: Belorusskiye blyuda. Minsk: Polymiya; 1966.

42. Bolotnikova VA, Vapel'nik LM, Korzun IP, Markova LD, Shapiro DK: Belorusskaya kuhnya. Minsk: Urazhday; 1977.

43. Svanberg I, Sõukand R, Łuczaj Ł, Kalle R, Zyryanova O, Dénes A, Papp N, Nedelcheva A, Šeškauskaitė D, Kołodziejska-Degórska I, Kolosova V: Uses of tree saps in northern and eastern parts of Europe. Acta Soc Bot Pol 2012 81(4):343-357.

44. Wiercińska J: Andriolli - świadek swoich czasów. Listy i wspomnienia. Wrocław: Ossolineum; 1976

45. Adam Onufrowicz. http://pl.wikipedia.org/wiki/Adam_Onufrowicz.

46. Chłapowski F: Ś.p. Marya z Skirmuntów Twardowska. Notatka biograficzna. Roczniki Towarzystwa Przyjaciół Nauk Poznańskiego 1908, 34:317-320. 1907.

47. Hryniewiecki B: Udział kobiety polskiej w rozwoju botaniki. Czasopismo Przyrodnicze 1933, 7(1-3):1-17.

48. Mowszowicz J: Twardowska Maria (1858-1907). In Słownik biologów polskich. Edited by Feliksiak S. Warszawa: PWN; 1987:548-549.

49. Jakubski A: Dybowski Władysław (1838-1910). Polski Słownik Biograficzny 1948, 6:44-45

50. Łuczaj Ł, Svanberg I, Köhler P: Marsh Woundwort, Stachys palustris L. (Lamiaceae) - an overlooked food plant. Genet Resour Crop Ev 2011, 58:783-793. 
51. Pietkiewicz C: Polesie Rzeczyckie. Kraków: Polska Akademia Umiejętności; 1928.

52. Łuczaj Ł, Dumanowski J, Köhler P, Mueller-Bieniek A: Manna grass (Glyceria) in Poland: the use and economic value of this wild cereal from the Middle Ages to the twentieth century. Hum Ecol 2012, 40:721-733.

53. Ciszewski S: Niektóre ciężary chłopskie w średniowiecznej Polsce. Prace Etnologiczne 1925, 1:85-207.

54. Pirożnikow E: Tradycyjne użytkowania dziko rosnących roślin leczniczych i pokarmowych we wschodniej części Podlasia. In Park krajobrazowy Puszczy Knyszyńskiej w systemie ochrony przyrody i edukacji środowiskowej. Materiaty konferencji "Parki krajobrazowe w I połowie XXI wieku — edukacja ekologiczna wczoraj i dziś na przykładzie Parku Krajobrazowego Puszczy Knyszyńskiej" 27-28 maja 2008 r. Edited by Górniak A, Poskrobko B. Supraśl: Park Krajobrazowy Puszczy Knyszyńskiej; 2008:64-79.

55. Pirożnikow E: Tradycja użytkowania roślin dziko rosnących na Podlasiu poszukiwanie smaków, zdrowia i zaspokojenia głodu. In Historie kuchenne: Rola i znaczenie pożywienia w kulturze. Edited by Stolična R, Drożdż A. Cieszyn-Katowice-Brno: Uniwersytet Śląski w Katowicach; 2010:188-200. Kłodnicki Z, Langer J (Series Editors): Bibliotheca Ethnologiae Europae Centralis vol. 2.

56. Romanization of Belarusian. http://en.wikipedia.org/wiki/ Romanization_of_Belarusian.

57. Łuczaj Ł, Zovko Končić M, Miličević T, Dolina K, Pandža M: Wild vegetable mixes sold in the markets of Dalmatia (southern Croatia). J Ethnobiol Ethnomed 2013, 9:1.

58. Łuczaj Ł, Pieroni A, Tardío J, Pardo-de-Santayana M, Sõukand R, Svanberg I, Kalle R: Wild food plant use in 21st century Europe: the disappearance of old traditions and the search for new cuisines involving wild edibles. Acta Soc Bot Pol 2012, 81(4):359-370.

59. Lévi-Strauss C: Le Cru et le Cui. Paris: Pion; 1964

60. Vandebroek I, Balick MJ: Globalization and loss of plant knowledge: challenging the paradigm. PLoS One 2012, 7(5):e37643.

61. Ceuterick M, Vandebroek I, Pieroni A: Resilience of Andean urban ethnobotanies: a comparison of medicinal plant use among Bolivian and Peruvian migrants in the United Kingdom and in their countries of origin. J Ethnopharmacol 2011, 136(1):27.

62. Łuczaj Łป, Kujawska M: Botanists and their childhood memories: an underutilized expert source in ethnobotanical research. Bot J Linn Soc 2012, 168:334-343.

63. Kang Y, Łuczaj $t$, Yes $S$, Zhang $S$, Kang J: Wild food plants and wild edible fungi of Heihe valley (Qinling Mountains, Shaanxi, central China): herbophilia and indifference to fruits and mushrooms. Acta Soc Bot Pol 2012, 81(4):405-413.

doi:10.1186/1746-4269-9-21

Cite this article as: Łuczaj et al:: Wild edible plants of Belarus: from Rostafiński's questionnaire of 1883 to the present. Journal of

Ethnobiology and Ethnomedicine 2013 9:21.

\section{Submit your next manuscript to BioMed Central and take full advantage of:}

- Convenient online submission

- Thorough peer review

- No space constraints or color figure charges

- Immediate publication on acceptance

- Inclusion in PubMed, CAS, Scopus and Google Scholar

- Research which is freely available for redistribution 